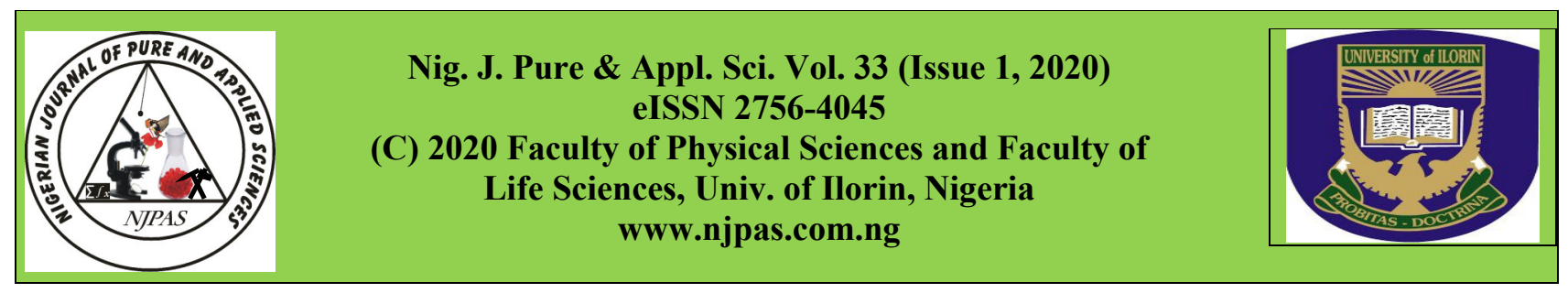

doi: http://dx.doi.org/10.48198/NJPAS/20.A13

\title{
Hepatoprotective effect of hydroethanol extracts of Allium sativum and Carica papaya on CCl4- induced liver damage in rats
}

Department of Biochemistry, Faculty of Science, Delta State University, Abraka, Delta State, Nigeria

\begin{abstract}
Plant-based products, believed to be less toxic have been employed as hepatoprotective agents in recent times. Polyherbal therapy is reported to have therapeutic benefits over single herb therapy. Allium sativum and Carica papaya are two known plants used traditionally for the treatment of liver related diseases. Thus, in this study, the hepatoprotective and antioxidant potential of hydroethanol extracts of Allium sativum cloves (Garlic) and Carica papaya (Pawpaw) leafs (singly and combined) against CCl4-induced toxicity in rats was evaluated. Thirty male albino rats used were classed into six (groups A- F) groups of five rats each and treated (orally) for 14 days. Group A- rats + distilled water (negative control); Group B- rats + CC14 in olive oil (positive control); Group C- rats $+200 \mathrm{mg} / \mathrm{kg}$-day combined extract of $A$. sativum and C. papaya (1: 1 ratio); Group D- rats + $200 \mathrm{mg} / \mathrm{kg}$-day extract of A. sativum; Group E- rats $+200 \mathrm{mg} / \mathrm{kg}$-day extract of C. papaya; Group F- rats + $100 \mathrm{mg} / \mathrm{kg}$ bw of silymarin. CCl4 induce hepatotoxicity was characterized by an upsurge $(\mathrm{P}<0.05)$ in serum Alkaline Phosphatase (ALP), Aspartate Aminotransferase (AST) and Alanine Transaminase (ALT) activities, and total bilirubin. Also, $\mathrm{CCl} 4$ administration led to a substantial reduction $(\mathrm{P}<0.05)$ of reduced glutathione (GSH), Glutathione peroxidase (GPx), superoxide dismutase (SOD) and catalase (CAT) activities and an increase $(\mathrm{P}<0.05)$ in lipid peroxidation $(\mathrm{MDA})$ in the liver tissue. However, treatment with hydroethanol extract of A. sativum and C. papaya prevented the $\mathrm{CCl} 4$ induced lipid peroxidation and returned the altered marker enzymes of serum and antioxidant enzymes level to near normal. The extracts of both plants demonstrated significant antioxidant and hepatoprotective activity as reflected by the results. Comparatively, the combined extract gave the most promising antioxidant and hepatoprotective potential, which may be due to positive synergistic effects of both plants over either plant used singly, thereby vindicating the use of polyherbal remedy over a single herb.
\end{abstract}

Keywords: Allium sativum, Carica papaya, hydroethanol, hepatoprotective, carbon tetrachloride, silymarin.

\section{Introduction}

Liver, being a main location where metabolism occurs, plays a central role in the detoxification of several toxins consumed, or formed during the absorption of food materials (Rane et al., 2016). Also, it plays a critical role in storage and secretion. Thus, the body relies on the liver for the regulation, production, storage and secretion of proteins, chemicals, nutrients and for purification and clearance of toxins/unnecessary body substances (Arige et al., 2017). Liver diseases are 
among the main causes of morbidity and mortality universally. Drug induced liver damage has been one of the very familiar causative factors that is of major clinical challenge. The symptoms of druginduced hepatotoxicity are extremely variable,

Page | 3640 reaching from asymptomatic rise of liver enzymes to liver failure (Russmann et al., 2009). Liver damage is always linked with cellular necrosis, upsurge in tissue lipid peroxidation, and reduction in tissue glutathione (GSH) levels. Also, there are elevated serum levels of several biochemical markers (serum glutamate pyruvate transaminase (SGPT/ALT), glutamate oxaloacetate transaminase (SGOT/AST) and alkaline phosphatase (Arige et al., 2017).

Plant-based products (being less toxic) have been employed as hepatoprotective agents in recent times. Hence, continual search of plant varieties for new hepatoprotective ability has been an active area of research (Afaf et al., 2008). Garlic (Allium sativum L.), is of the Liliaceae family, which originated from Central Asia. It is one of the earliest of cultivated plants (Londhe et al., 2011), and one of the timeliest documented plants used in the management of diseases and preservation of health. Garlic is used in several countries/cultures as a food element due to its typical flavor and prospective health benefits. Its biological activities (antioxidant, antibacterial and antifungal properties) have also been reported, which result from its organosulfur and polyphenols (Shrestha et al., 2016). Garlic contains a varied array of phenolic compounds like anthocyanins and phenolic acids (Phan et al., 2019). It is also rich in minerals and vitamins. In Africa, especially in Nigeria, garlic is used in the treatment of respiratory tract infections, abdominal discomfort, otitis media and diarrhea. Similarly, ascorbic acid mixture with garlic has been said to shield the liver against $\mathrm{Cd}$ induced toxicity in albino mice (Kaur and Sharma, 2015). Several cultures have accepted the probable use of garlic for preclusion and management of diverse diseases. Distinctive compounds found in garlic are believed to possess anti-microbial and antitumor effects and lessen the risk for cardiovascular disorders (Bayan et al., 2014).

Papaya (Carica papaya L.), also known as pawpaw, is of the Caricaceae family involving 31 species in four genera. Papaya contains phytochemicals such as carotenoids, glucosinolate, alkaloids and phenolics. Others include Lycopene, Betacryptoxanthin Betacarotinoid, protocatachuic acid, Benzylisothyocynate, chlorogenic acid, Benzylglucosinolate, Quercetin and caffeic acid (Huang et al., 2009). The fruits, seeds, leaves, flower, juice, root and stem bark of the plant have been described to possess antimicrobial, antifungal, anthelmintic, antimalarial, hepatoprotective, male/ female antifertility, antiinflammatory anti-cancer, hepatoprotection, antioxidant and anti-dengue properties (Karishna et al., 2008; Nugroho et al., 2017). The nephroprotective activity of Carica papaya plant on $\mathrm{CCl} 4$ induced renal injured rats has been reported (Olagunjua et al.,2009).

The practice of herb-herb combinations, otherwise known as polyherbal therapy has existed for several years, but the scientific proof of their therapeutic benefits is wanting in the literature. Also, hopeful effect of drug combination over a single drug in disease treatment has been reported (Karole, 2019). Similarly, the content of bioactive compounds from plants differ subject to the environmental factors, post-harvest conditions, agronomic conditions and maturity (Martins et al., 2016). Therefore, this study was directed at comparing the hepatoprotective and antioxidant potential of hydroethanol extracts of Allium sativum and Carica papaya leafs (singly and combined) against $\mathrm{CCl} 4$-induced toxicity in rats. 


\section{Materials and Methods}

\section{Drug and chemicals}

Silymarin and Carbon tetrachloride (CC14) were purchased from Sigma chemicals, USA. Serum Page | 3641 Glutamate Oxaloacetate Transaminase (SGOT/AST), Serum Alkaline Phosphatase (ALP), Serum Glutamate Pyruvate Transaminase (SGPT/ALT), Serum Total bilirubin (TB), Albumin and Total protein kits were purchased from RANDOX Laboratories Ltd., Ardmore, UK. All other chemicals for this study were of analytical grade.

\section{Collection and preparation of plant materials}

Carica papaya leaves were collected form Site II of the Delta State University, Abraka, while the garlic cloves were purchased from Abraka market and were both authenticated by Dr. H. A. Akinnobosun of the Department of Plant Science (Herbarium Unit), University of Benin, with voucher numbers: $\mathrm{UBH}_{\mathrm{A}} 388$ (Garlic) and $\mathrm{UBH}_{\mathrm{C}} 505$ (Pawpaw). The samples were separately washed in running water tap, cut into tiny pieces, air dried and extracted with hydroethanol (ethanol: water, $50: 50 \mathrm{v} / \mathrm{v}$ ) as described by Okoro et al., 2014. The extracts were kept at $4{ }^{\circ} \mathrm{C}$ before use. The dried extract was suspended in distilled water to prepare the concentration $(200 \mathrm{mg} / \mathrm{kg} \mathrm{bw})$ used in this study.

\section{Animals}

The male rats (weighing $150-220 \mathrm{~g}$ ) used for the study were bought from the Anatomy Department of Delta State University, Abraka, Nigeria. They were fed grower's mash (Top Feed, Ltd, from Sapele in Delta State) and water ad libitum. They were maintained in agreement with the guidelines on the care and wellbeing of research animals.

\section{Grouping and treatment}

The male albino rats were grouped into six (groups A- F) groups of five rats each and were treated orally for 14 days as follows:
Group A-Animals + distilled water only (negative control).

Group B-Animals + CCl4 in olive oil vehicle only (positive control).

Group C-Animals $+200 \mathrm{mg} / \mathrm{kg}$-day combined extract of A. sativum and C. papaya (Mixture of both extracts in ratio of $1: 1$ )

Group D-Animals $+200 \mathrm{mg} / \mathrm{kg}$-day hydroethanol extract of A. sativum.

Group E-Animals $+200 \mathrm{mg} / \mathrm{kg}$-day hydroethanol extract of C. papaya

Group F-Animals $+100 \mathrm{mg} / \mathrm{kg}$ bw of silymarin.

Treatment of the rats continued for 14 days and groups B $-\mathrm{F}$ animals were injected intraperitoneally with $\mathrm{CCl} 4$ in olive oil vehicle at a dosage of $(1 \mathrm{ml} / \mathrm{kg} \mathrm{bw})$ on the 14th day (30 $\mathrm{min}$ after the last treatment). The animals were fasted and sacrificed by cardiac puncture, $24 \mathrm{~h}$ after $\mathrm{CCl} 4$ administration to obtain the serum and liver tissue used for the assays of this study.

\section{Serum biochemical parameters determination}

Serum samples were used for hepatic function tests using standard diagnostic kits (from RANDOX Laboratories Ltd., Ardmore, UK), by the following methods: Albumin (Gornall et al.,1949), Total bilirubin (Trinder, 1969), Total protein (Jendrassik and Grof, 1938), alkaline phosphatase (Doumas et al., 1971), alanine aminotransferase (Reitman and Frankel, 1957) and aspartate aminotransferase (Sood, 1999).

\section{Oxidative stress markers determination}

The following methods were used for the assays: The levels of antioxidants in liver tissue (SOD, CAT, GSH and GPx) were estimated by the method of Marklund (1992), Sinha (1972), Ellman (1970) and Rotruck et al. (1973) respectively. While, Lipid peroxidation byproduct [malondialdehyde (MDA)] in liver tissue was by Ohkawa et al. (1979). 


\section{Statistical analysis}

Data are presented as mean \pm standard deviation and compared by the analysis of variance (ANOVA), and Turkey's post hoc test (for Page | 3642 statistical significance) using GraphPad Prism (6.0 version). Significant level was at $\mathrm{p}<0.05$.

\section{Results}

\section{Biochemical changes in serum parameters}

The effects of hydroethanol extracts of A. sativum and $C$. papaya on liver functioning of $\mathrm{CCl} 4$ intoxicated rats after 14 days treatment is shown in Figures 1-6. Single dose of CCl4 administration significantly $(\mathrm{p}<0.05)$ increased the levels of ALT, ALP and AST in the positive control group, compared to the negative control group. Also, a significant $(p<0.05)$ increase in the level of TB was seen in the positive control animals compared to the negative control group. On the other hand, pre-treatment with either the extract or the standard drug significantly $(\mathrm{p}<0.05)$ reduced the levels of hepatic enzymes of serum (ALT, AST and ALP) and TB, when compared with the positive control group. The reduction in hepatic serum enzymes were in the following order: $\mathrm{F}>$ $\mathrm{C}>\mathrm{D}>\mathrm{E}(\mathrm{ALT}) ; \mathrm{C} / \mathrm{F}>\mathrm{D}>\mathrm{E}(\mathrm{AST}) ; \mathrm{F}>\mathrm{C}>\mathrm{E}>\mathrm{D}$ (ALP); $\mathrm{F}>\mathrm{C} / \mathrm{D} / \mathrm{E}$ (TB). However, lower level of albumin and total protein were noticed in the positive control rats, compared with the negative control group of rats. While significantly $(p<0.05)$ higher levels of these two parameters were seen in the rats given either extracts or the standard drug, with the combined extract group (D) showing values for albumin and total protein near normal.

\section{Superoxide dismutase (SOD) and catalase (CAT) activities}

The activity of SOD in liver tissue homogenate was significantly decreased in $\mathrm{CCl} 4$ treated animals, compared with negative control. However, pretreatment with both extracts and the standard drug showed significant increase in SOD activity in all treated groups (Figure 7). Similarly, the CAT activity in $\mathrm{CCl} 4$ treated rats (positive control) was significantly $(p<0.05)$ decreased when compared to negative control group. Again, pretreatment with both extracts significantly restored the CAT activity (Figure 8). Similarly, treatment with the standard drug appreciably increased the catalase activity (Figure 8).

\section{Lipid Peroxidation (LPO) level, Glutathione (GSH) and Glutathione Peroxidase (GPx) Activities}

Effect of A. sativum and C. papaya extracts on LPO were measured by the formation of free MDA in the liver tissue following exposure to CCL4, and shown in Figure 9. Upon CCL4 administration, MDA levels increased significantly $(\mathrm{p}<0.05)$ in the positive control rats. However, treatment with either extract or the standard drug significantly inhibited the formation of MDA in the treated groups. On the other hand, a significant $(\mathrm{p}<0.05)$ decrease in GSH concentration was observed in CCL4 treated rats (positive control) compared with the negative control group. Administration of the hydroethanol extract of A. sativum and C. papaya for 14 consecutive days afforded a protection against GSH depletion in the treated groups (Figure 10).

The activity of Glutathione Peroxidase in the different treated groups of rats is shown in Figure 11. Significant decrease $(p<0.05)$ in GPx activity was observed for the CCL4 treated rats, while treatment with the $A$. sativum and C. papaya extract caused a significant increase $(\mathrm{p}<0.05)$ in the extract treated rats when compared with the CCL4 treated rats. Similarly, a significant increase $(p<0.05)$ was also observed in the silymarin treated groups compared with the positive control group (Figure 11). 


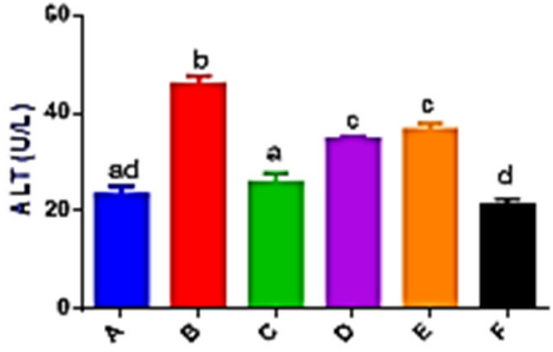

Figure 1: Effects of hydroethanol extracts ( $A$. sativum and $C$. papara) and silymarin on alanine aminotransferase (ALT) activity

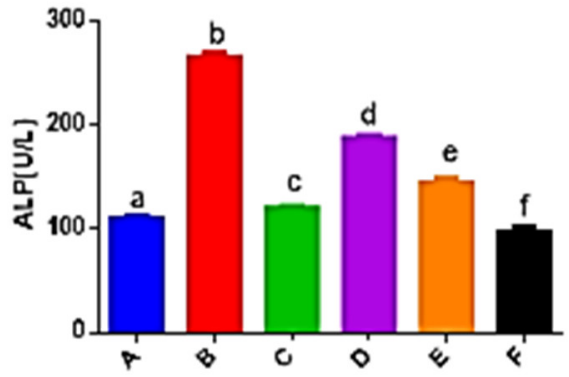

Figure 3: Effects of hydroethanol extracts (A. Figure 4: Effects of hydroethanol extracts (A. sativum and $C$ papaya) and silymarin on alkaline phosphatase (ALP) activity

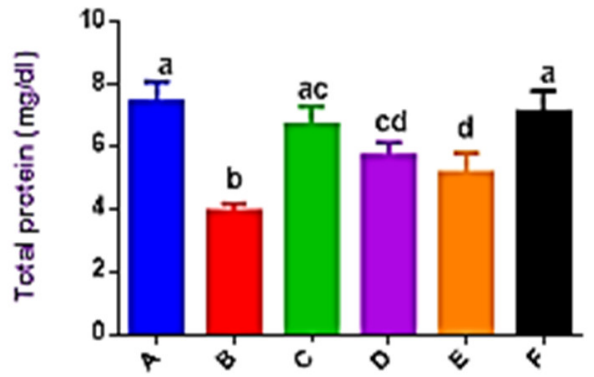

Figure 5: Effects of hydroethanol extracts (A. Figure 6: Effects of hydroethanol extracts (A sativum and $C$. paparya) and silymarin on Total protein (TP) level

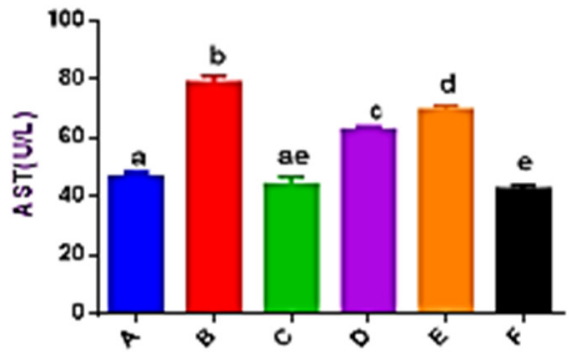

Figure 2: Effects of hydroethanol extracts (A. sativum and $C$. paparia) and silymarin on aspartate aminotransferase (AST) activity

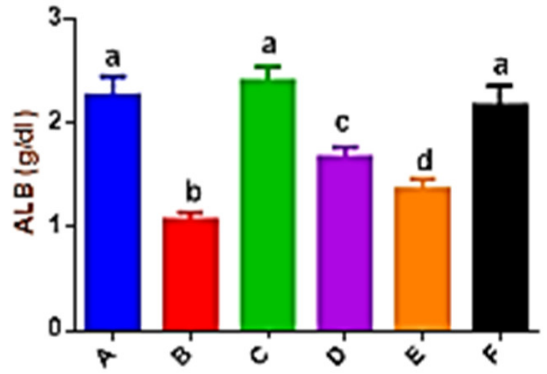

sativum and C. paparia) and silymarin on Albumin (ALB) level

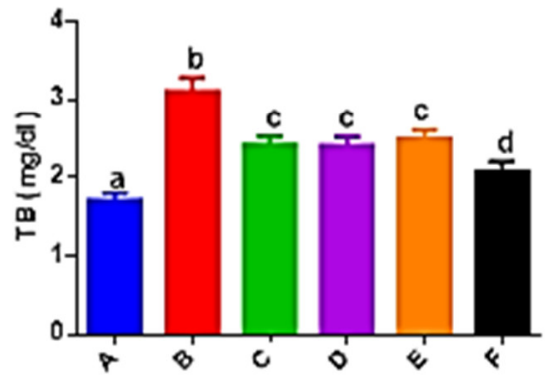
sativum and C. papoya) and silymarin on Total bilirubin (TB) level

*Bars with unlike letters differ considerably $(\mathrm{p}<0.05) . * *$ Keys : $\mathrm{A}=$ rats + distilled water (negative control); $\mathrm{B}=$ rats $+\mathrm{CCl} 4$ in olive oil (positive control); $\mathrm{C}=$ rats $+200 \mathrm{mg} / \mathrm{kg}$-day combined extract of $\boldsymbol{A}$. sativum and C. papaya (1: 1 ratio); D = rats $+200 \mathrm{mg} / \mathrm{kg}$-day extract of $A$. sativum; $\mathrm{E}=$ rats $+200 \mathrm{mg} / \mathrm{kg}$-day extract of $C$. papaya; $\mathrm{F}=$ rats $+100 \mathrm{mg} / \mathrm{kg} \mathrm{bw}$ of silymarin. 


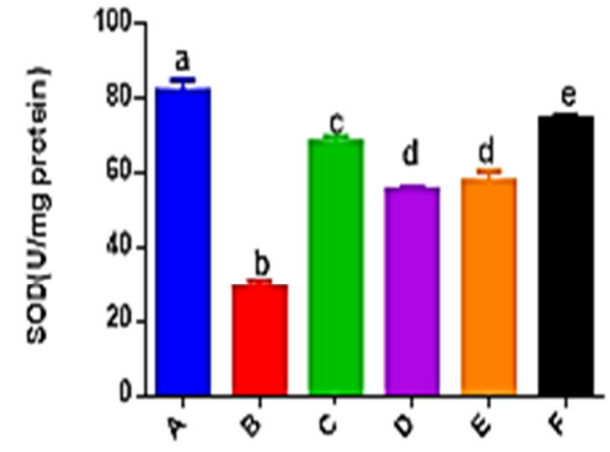

Figure 7: Effects of hydroethanol extracts (A. Figure 8: Effects of hydroethanol extracts ( $A$. sativum and $C$. papara) and silymarin on Superoxide dismutase (SOD) level

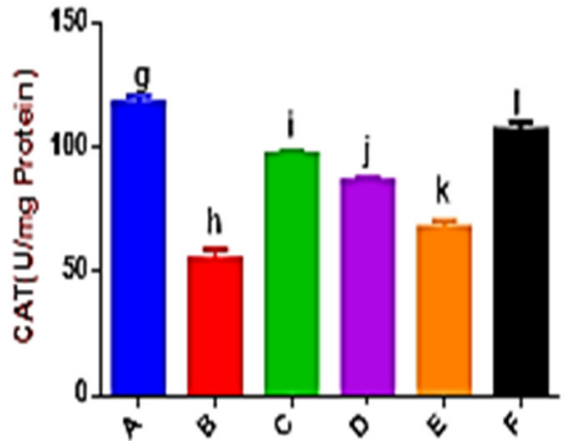

sativum and $C$. papaya) and silymarin on Catalase (CAT) level

*Bars with unlike letters differ considerably $(\mathbf{p}<0.05) * *$ Keys : A= rats + distilled water (negative control); $B=$ rats + CCl4 in olive oil (positive control); $C=$ rats $+200 \mathrm{mg} / \mathrm{kg}$-day combined extract of $A$. sativum and C. papaya (1: 1 ratio); $\mathrm{D}=$ rats $+200 \mathrm{mg} / \mathrm{kg}$-day extract of $A$. sativum; $\mathrm{E}=$ rats $+200 \mathrm{mg} / \mathrm{kg}$-day extract of C. papaya; $F=$ rats $+100 \mathrm{mg} / \mathrm{kg}$ bw of silymarin.

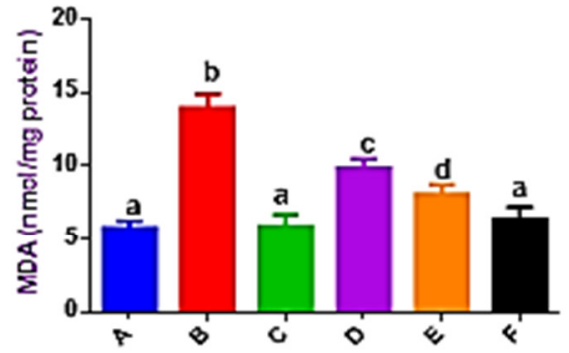

Figure 9: Effects of hydroethanol extract sativum and $C$. paxpaya) and silymarin Malondialdehyde (MDA) level

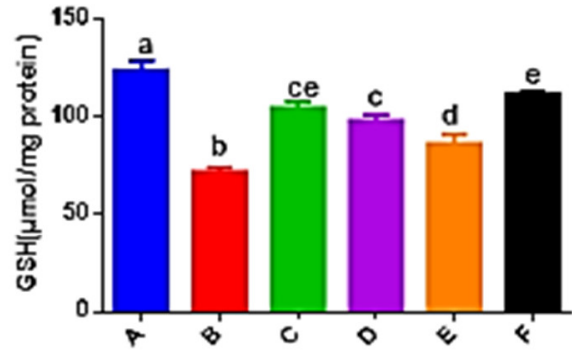

(A) Figure 10: Effects of hydroethanol extracts ( $A$. on sativum and $C$. papaya) and silymarin on Glutathione (GSH) level

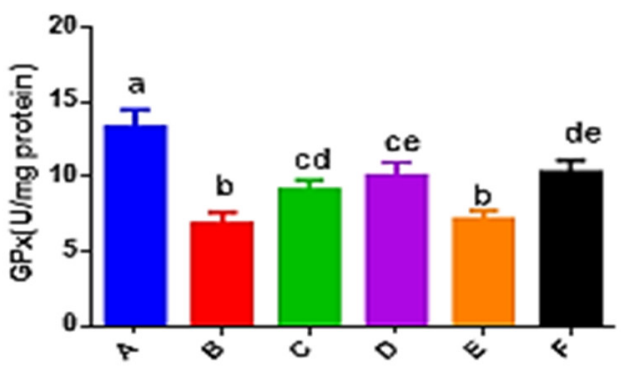

Figure 11: Effects of hydroethanol extracts (A. sativum and $C$. papoy $\alpha$ ) and silymarin on Glutathione peroxidase (GPx) activity

*Bars with unlike letters differ considerably $(\mathbf{p}<0.05) * *$ Keys: $\mathrm{A}=$ rats + distilled water (negative control); B $=$ rats + CCl4 in olive oil (positive control); $\mathrm{C}=$ rats $+200 \mathrm{mg} / \mathrm{kg}$-day combined extract of $A$. sativum and $C$. papaya (1: 1 ratio); D = rats $+200 \mathrm{mg} / \mathrm{kg}$-day extract of $A$. sativum; E $=$ rats $+200 \mathrm{mg} / \mathrm{kg}$-day extract of $C$. papaya; $\mathrm{F}=$ rats $+100 \mathrm{mg} / \mathrm{kg}$ bw of silymarin. 


\section{Discussion}

The defensive roles of certain herbal extracts on intoxicated liver cells have been reported (Ajiboye et al., 2010; Bag and Mumtaz, 2013).

Page | 3645 Amongst xenobiotics, CCl4 is a key causative agent of severe liver cell injury through free radical generation (Guo et al., 2017). In this study, the hepatoprotective and antioxidant potential of hydroethanol extracts of Allium sativum and Carica papaya leafs (singly and combined) were compared against $\mathrm{CCl} 4$-induced toxicity in rats.

Aspartate aminotransferase (AST) is mostly located in mitochondria of hepatocytes. ALT is specifically found in the liver, and hence a better parameter for identifying liver injury. Also, ALP and bilirubin is connected with liver injury (Girish et al., 2009). Results of this experiment show an increase in the serum levels of ALT, ALP, AST and TB in the positive control group when compared to the negative control group, following a single dose of $\mathrm{CCl} 4$ administration. This observation agrees with earlier reports that administration of $\mathrm{CCl} 4$ led to a significant increase in the levels of AST, ALP and ALT, which may be ascribed to destruction of the structural integrity of liver, since they are localized in the cytoplasm and must have been discharged into circulation following cellular damages signifying occurrence of hepatotoxicity (Gutiérrezl and Solís, 2009). But, pretreatment with either extracts or the combined extract caused an appreciable reversal of the $\mathrm{CCl} 4$ induced alteration of the liver marker enzymes, with the combined extract giving the best result among the extracts. During liver damage, cellular enzymes like ALT, ALP and AST present in the hepatic cells, escape into the serum leading to a surge in their concentration. The decrease in raised serum levels of the liver marker enzymes following extract treatment in groups $\mathrm{C}-\mathrm{E}$ may be partly due to the protective effect of Allium sativum and Carica papaya plants extracts on hepatocytes following the renewal of the liver cell membrane permeability (Ghanbari et al., 2016). This protective effect shown signifies a decrease in enzymes existing in the liver cell's extra cellular milieu (Sarkar and Sil, 2007).

In this study, the administration of CCl4 led to a decrease in the albumin and total protein levels in the positive control group relative to the negative control/normal rats. A decline in total protein may be as a result of disruption and severance of polyribosome on endoplasmic reticulum heading to flawed protein biosynthesis (Dubey et al., 1994). Pretreatment with extracts of either plant improved the serum ALB and TP levels with variable degree of significance in groups $\mathrm{C}-\mathrm{E}$, the best result being obtained from the combined extract group. This observed improvement may be as a result of the elevation of the assemblage of ribosome on endoplasmic reticulum to expedite continuous protein biosynthesis (Sabbani et al., 2016).

The liver and kidney are the primary focus organs of $\mathrm{CCl} 4$ toxicity, and once $\mathrm{CCl} 4$ is metabolically activated, then free radical reactions are started resulting in oxidative stress and subsequently peroxidation of cellular lipids (Tirmestein et al., 2007). The CCl4 action result from its free radical transformation to a trichloromethyl radical which binds to macromolecules in liver cells membrane. Glutathione peroxidase (GPx), superoxide dismutase (SOD) and catalase (CAT) are important enzymes vital in the enzymatic antioxidant defense system, where they act to scavenge hydrogen peroxide and superoxide ion and defend the cells against lipid peroxidation. These antioxidant enzymes counteract the production of hydroxyl radical and shield the cellular components from oxidative damage (Scott et al., 1991).

In this study, the administration of $\mathrm{CCl} 4$ to animals resulted to an increase in liver tissue MDA level. Also, the activities of SOD, CAT, 
Page | 3646 concerned with the elimination of free radical species like alkoxy radicals, hydrogen peroxide and superoxide radicals and also acts as substrate for glutathione peroxidase (Prakash et al., 2001). A decreased level of GSH observed in this study was related with an increased lipid peroxidation in the CCl4-treated rats. However, pretreatment with either extracts or the combined extract showed a great capability of the extracts to decrease oxidative stress by normalizing SOD and CAT levels. Similarly, the glutathione and MDA levels were enhanced by treatment with extracts of both plants, thereby precluding lipid peroxidation. Thus, both plants extract possess antioxidant and hepatoprotective effect by regulatory action on suppressing oxidative stress and cellular permeability. Previous findings signified that specific steroids, flavonoids and triterpenoids possess hepatoprotective effect due to their antioxidant properties. Phenolic compounds are known to be the most significant antioxidative constituents of herbs/plant materials (Gupta and Misra, 2006).

A good relationship between the total antioxidant capacities and the concentrations of plant phenolic has been reported (Pellegrini et al., 2000). Phytochemically, C. papaya contains carotenoids, glucosinolate, alkaloids, phenolics, Lycopene, Betacryptoxanthin Betacarotinoid, protocatachuic acid, Benzylisothyocynate, chlorogenic acid, Benzylglucosinolate, Quercetin and caffeic acid (Huang et al., 2009), while the presence of phenolic compounds like anthocyanins and phenolic acids, have been reported for A. sativum (Bozin et al., 2008; Phan et al., 2019). In this study, both extracts used, either singly or combined demonstrated significant antioxidant and hepatoprotective activity as reflected by the results for serum hepatic marker enzymes and the liver tissue antioxidant parameters, with the combined extract giving the most promising antioxidant and hepato-protective capacity. Therefore the observed effect may be due to positive synergistic effect of both plants over either plant used singly (Karole, 2019), and may also be attributed to the phytoconstituents of the extracts, which agrees with earlier reports on the antioxidant and hepatoprotective properties of $A$. sativum (Kaur and Sharma, 2015; Shrestha et al., 2016) and C. papaya (Nugroho et al., 2017).

\section{Conclusion}

The induction of liver damage by $\mathrm{CCl} 4$ in this study was characterized by a rise in tissue lipid peroxidation and reduction of reduced glutathione levels. Also, serum levels of various biochemical markers such as ALT, ALP and AST were raised above normal. However, treatment with either extract of $A$. sativum / $C$. papaya or the combine extract at $200 \mathrm{mg} / \mathrm{kg}$,bw significantly reduced the raised serum levels of the markers enzymes and prevented the $\mathrm{CCl} 4$ induced lipid peroxidation and returned the antioxidant enzymes level to near normal. The results have shown the hepatoprotective activity of the extracts with the combined extract exhibiting a more promising activity overall among all extracts.

\section{References}

Afaf, I. A., Nuha, H.S. and Mohammed, A.H. (2008). Hepatoprotective effect of Eclipta alba against carbon tetrachloride-induced damage in rats. Research Journal of Animal and Veterinary Sciences. 3:20-3.

Ajiboye, T.O., Yakubu, M.T., Salau, A.K., Oladiji, A.T., Akanji, M.A. and Okogun, J.I. (2010). Antioxidant and drug detoxification potential of aqueous extract of Annona senegalensis leaves in carbon tetrachloride-induced hepatocellular 
damage. Pharmaceutical Biology. 48:136170 .

Arige, S. S., Arige, S.D. and Lakshmana Rao, A. (2017). "A review on Hepatoprotective Page | 3647 activity", International Journal of Current Research. 9(06): 51876-51881.

Bag, A.K. and Mumtaz, S.M. (2013). Hepatoprotective and nephroprotective activity of hydroalcoholic extract of Ipomoea staphylina leaves. Bangladesh Journal of Pharmacology. 8:263-8.

Bayan, L., Koulivand, P.H. and Gorji, A. (2014). Garlic: a review of potential therapeutic effects. Avicenna Journal of Phytomedicine. 4 (1): 1-14.

Phan, A. D. T., Netzel, G., Chhim, P., Netzel, M.E. and Sultanbawa, Y. (2019). Phytochemical Characteristics and Antimicrobial Activity of Australian Grown Garlic (Allium Sativum L.) Cultivars. Foods. 8(9): 2.

Doumas, B.T., Watson, W. and Briggs, H.G. (1971). Albumin standards and the measurement of serum albumin with bromocresol green. Clinica Chimica Acta. 31: 87-96.

Dubey, G.P., Agarwal, A. and Dixit, S.P. (1994). Effect of Liv-52 on different biochemical parameters in alcoholic cirrhosis. The Antiseptic. 91: 205-208.

Ellman, G. L. (1970). "SH groups determination in biological fluids." Analytical Biochemistry. 46: 237-240.

Ghanbari, E., Nejati, V. and Khazaei, M. (2016). Improvement in serum biochemical alterations and oxidative stress of liver and pancreas following use of royal jelly in streptozotocin-induced diabetic rats. Cell Journal. 18(3): 362-370.
Girish, C., Koner, B.C., Jayanthi, S., Rao, K.R., Rajesh, B. and Pradhan, S.C. (2009). Indian Journal of Medical Research. 129(5): 569578.

Gornall, A.G., Bardwill, C.J. and David, M.M. (1949). Determination of serum proteins by means of biuret reaction. Journal of Biological Chemistry. 177: 751-66.

Guo, S., Guo, T., Cheng, N., Liu, Q., Zhang, Y. and Bai, L. (2017). Hepatoprotective standardized EtOH-water extract from the seeds of Fraxinus rhynchophylla hance. Journal of Traditional and Complementary Mededicine. 7:158-64.

Gupta, A.K. and Misra, N. (2006). Hepatoprotective activity of aqueous ethanolic extract of Chamomile capitula in paracetamol intoxicated albino rats. American Journal of Pharmacology and Toxicology. 1: 17-20.

Gutiérrezl, R.M.P. and Solís, R.V. (2009). Hepatoprotective and inhibition of oxidative stress in liver of Prostechea michuacana. Records of Natural Products. 3(1): 46-51.

Huang, W.Y., Cai, Y.Z. and Zhang, Y. (2009). Natural phenolics compounds from medicinal herbs and dietary plants: potential use for cancer prevention. Nutrition and Cancer. 62(1): 1-20.

Jendrassik, L. and Grof, P. (1938). Colorimetric Method of Determination of bilirubin. Biochemische Zeitschrift. 297:81-82.

Kalab, M. and Krechler, T. (1997). The effect of the heptoprotective agent Liv-52 on liver damage. Casopís lékař̃ českých. 136:75860.

Karishna, K.L., Paridhavi, M. and Patel, J.A. (2008). Review on nutritional, medicinal and pharmacological properties of papaya 
(Carica papaya Linn.). Nat Prod Radiance. 7: 364-373.

Karole, S., Shrivastava, S., Thomas, S., Soni, B., Khan, S., Dubey, J., Dubey, S.P., Khan, N. Page | 3648 and Jain, D.K. (2019). Polyherbal Formulation Concept for Synergic Action: A Review, Journal of Drug Delivery and Therapeutics. 9(1-s):453-466.

Kaur, S. and Sharma, S. (2015). A histometric study to assess preventive action of ascorbic acid and garlic on cadmium induced hepatotoxicity in albino mice. International Journalof Pharmaceutical and Phytopharmacological Research. 5: 398.

Londhe, V.P., Gavasane, A.T., Nipate, S.S., Bandawane, D.D. and Chaudhari, P.D. (2011). Role of garlic (Allium Sativum) in various diseases: An overview. Journal of Pharmaceutical Research and Opinion.1:129-34.

Marklund, S. L. (1992). "Regulation by cytokines of extracellular superoxide dismutase and other superoxide dismutase isoenzymes in fibroblasts," The Journal of Biological Chemistry. 267(10): 6696-6701.

Martins, N., Petropoulos, S. and Ferreira, I.C.F.R. (2016). Chemical composition and bioactive compounds of garlic (Allium sativum L.) as affected by pre- and postharvest conditions: A review. Food Chemistry. 211: 41-50.

Mathur, S. (1994). Role of Liv-52 in protection against beryllium intoxication. Biological Trace Element Research. 41:201-15.

Nugroho, A., Heryani, H., Choi, J.S. and Park, H.J. (2017). Identification and quantification of flavonoids in Carica papaya leaf and peroxynitrite scavenging activity. Asian Pacific Journal Tropical Biomedicine. 7(3): 208-213.
Ohkawa, H., Onishi, N. and Yagi, K. (1979) Assay of lipid peroxidation in animal tissue by thiobarbituric acid reaction. Analytical Biochemistry. 95: 351-358.

Okoro, I.O., Umar, I. A., Atawodi, S.E. and Anigo, K.M. (2014). Antidiabetic effect of Cleome rutidosperma DC and Senecio biafrae (Oliv. \& Hiern) extracts in streptozotocin-induced diabetic rats. International Journal of Pharmaceutical Sciences and Research. 5(6): 2480-97.

Olagunjua, J.A., Adeneyeb, A.A., Fagbohunkac, B.S., Bisugac, N.A., Ketikuc, A.O., Benebod, A.S., Olufowobic, O.M., Adeoyec, A.G., Alimic, M.A. and Adelekec, A.G. (2009). Nephroprotective activities of the aqueous seed extract of Carica papaya Linn. in carbon tetrachloride induced renal injured Wistar rats: a doseand time-dependent study. Biology and Medicine. 1(1): 11-19.

Pellegrini, N., Simonetti, P., Gardana, C. and Brenna, O. (2000). Brighenti activity of Vini Novelli (Young red wines). Journal of Agriculture and Food Chemistry. 48: 732735.

Prakash, J., Gupta, S.K., Kochupillai, V., Singh, N., Gupta, Y.K. and Joshi, S. (2001). Chemo preventive activity of Withania somnifera in experimentally induced fibrosarcoma tumors in swiss albino mice. Phytotherapy Research. 15: 240-244.

Rane, J., Kadhai, R. and Bakal, R.L. (2016). Liver diseases and herbal drugs: A review. Journal of Innovations in Pharmaceutical and Biological Sciences. 3: 24-36.

Reitman, S. and Frankel, S.A. (1957). Colorimetric method for the determination of serum glutamic oxaloacetic and glutamic pyruvic transaminases. American Journal of Clinical Pathology. 28: 56-63. 
Rotruck, J.T., Pope, A.L., Ganther. H.E., Swanson, A.B., Hafeman, D.C. and Hoekstra, W.G. (1973). Selenium: biochemical roles as a component of glutathione peroxidase, Science.179 (73): 588-590.

Russmann, S., Gerd, A., and Grattagliano, I. (2009). Current concepts of mechanisms in drug-induced hepatotoxicity. Current Medicinal Chemistry. 16: 3041-3053.

Sabbani, P.K., Thatipelli, R.C., Surampalli, G. and Duvvala, P. (2016). Evaluation of Hepatoprotective Activity with different Fractions of Gardenia gummifera Linn. on Paracetamol Induced Liver Damage in Rats. Journal of Drug Metabolism and Toxicology. 7: 199. doi:10.4172/21577609.1000199 .

Sarkar, M.K. and Sil, P.C. (2007). Hepatocytes are protected by herb Phyllanthus niruri protein isolate against thioacetamide toxicity. Pathophysiology. 14(2): $113-20$.

Scott, M.D., Lubin, B.H., Zuo, L. and Kuypers, F.A. (1991). Erythrocyte defense against hydrogen peroxide: Preeminent importance of Catalase. Journal of Laboratory and Clinical Medicine. 118: 7-16.

Shrestha, D.K., Sapkota, H., Baidya, P. and Basnet, S. (2016). Antioxidant and Antibacterial Activities of Allium sativum and Allium Cepa. Bulletin of Pharmaceutical Research. 6: 50-55.

Sinha, A.K. (1972). Colorimetric assay of catalase. Analytical Biochemistry. 47: 389394.

Sood, R. (1999). Medical Laboratory Technology, Methods and Interpretation. 5ed. Jaypee Brothers Medical Publishers Ltd. pp. 488-490.
Tirmestein, M., Leraas, T. and Farris, M. (2007). $\alpha$-Tocopherol hemisuccinate administration increases rat liver subcellular a-tocopherol levels and protects against carbon tetrachloride-induced hepatotoxicity. Toxicology Letters. 92:67-77.

Trinder, P. (1969). Determination of glucose in blood using glucose oxidase with an alternative oxygen acceptor. Annals of Clinical Biochemistry. 6: 24-27. 